合成した AA の赤外收取スペクトルを図6に示す。

3.4.2 留分B(III) のケトン分解: Schechter ら日)の方法にし たがって留分Bをケトン分解して AA をえた。収率 70\%，bp $127^{\circ} \sim 134^{\circ} \mathrm{C}$ 。

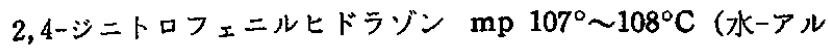
コール): 即知のサンプル (3.4.1) との混融によって融点の降下 をみない。

\section{$3.5 \mathrm{~V}$ の合成}

II $10 \mathrm{~g}(0.1 \mathrm{~mol})$ と cis-, trans-第一菊酸クロリド $19.6 \mathrm{~g}$ (0.105 mol) とをピリジ $12 \mathrm{~g}(0.15 \mathrm{~mol})$ の存在でベンゼン中 で縮台させてVを得た。粗取量 $23.4 \mathrm{~g}(93.6 \%)$ 。 b $0.0687^{\circ} \sim$ $90^{\circ} \mathrm{C}, n_{\mathrm{D}}^{25} 1.4634_{\text {。 }}$

分析值 C $76.71 \%$ H $10.49 \%$

$\mathrm{C}_{16} \mathrm{H}_{26} \mathrm{O}_{2}$ としての計算值 C $76.75 \%, \mathrm{H} 10.47 \%$

V す家蠅 (Musca domestica L.) に対する殺虫性を試験したが, Knock-down 抢よび殺虫力はいずれもほとんどみられなかった。

\section{4 結語}

ナトリウムエチラートを縮合刜としてアリルアセトンと炭酸シ エチルエステルとの縮合によって 3-オキソ-6-ヘプテン酸エチル
エステルを合成する Claisen 反応において，1-ヘキセン-5-イル 炭酸エチルエステルが副生し，これはアリルアセトンがナトリゥ ムエチラートによって還元をうけて 1-ヘキャン-5-オールを生成 し，ついでこれと炭酸シエチルエステルとの間にエステル交換度 応がおこって生成するむのであることを明らかにした。また副 生した 1-ヘキセン-5-イル炭酸エチルエステルの加水分解によっ て得られる 1-ヘキセン-5-オールの赤外吸収スペクトルにおける $1725 \mathrm{~cm}^{-1}$ の異常吸収蒂から, 1,5-ヘキサジンン-2-イル炭酸エチ ルエステルが同時に副生することを推定した。これらの副生成物 は，この Claisen 反応に打ける O-置換生成物とみられ，一方， 主生成物 の3-オキソ-6-ヘプテン酸エチルエステルのほかに

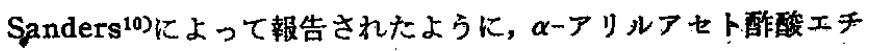
ルエステルが副生することを確認した。これらの生成物はこの Claisen 反応に括ける C-置換生成物である。

本研究にあたり御琶篤な御指導觉晹わった大阪大学理学部金子 武夫教投に愿く御礼申し上げるとともに，本研究の発表觉許可さ れた住友化学工業㧣式会社, 実殹に協力された同社技帥岡野 茂, 望月雅郎両氏ならびに赤外吸収スペクトル測定の学をとられた同 社技師大井尚文博士に厚く感謝致します。

\title{
タデの辛味成分タデオナールの構造
}

(明和 37 年 2 月 1 日受 理)

\author{
大 須 賀 昭 夫†
}

タデの辛味成分は川口により $\mathrm{C}_{15} \mathrm{H}_{22} \mathrm{O}_{2}$ のシケトンと報告され，タデオンと命名されている。著者はとのるのと同じ分子式をも

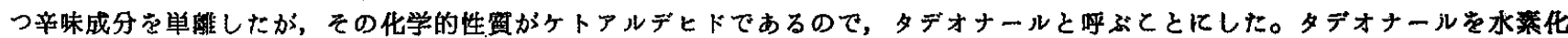

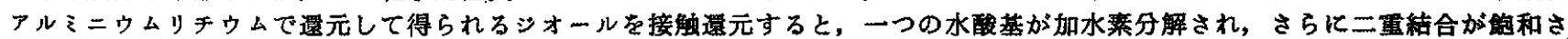
れてモノアルコールが得られる。てのものを酸化して得られるカルボン酸は Appel らがドリメノールから誉いたドリマニン酸と 一致した。それゆえタデオナールに式（I）苍推定した。

\section{1 緒}

「たでくう虫もすきすぎ」という言葉からひろく知られている タデは新鮮感のとむなう 1 種の香気と,きわめて強い刺激性の辛 味をもっていて，アユの塩焼の調味料として 欠くことのできな いものである。この辛味成分については，川口らりはヤナギタデ (Polygonum Hydropiper L.) の瓜乾葉から bp $159^{\circ} \sim 160^{\circ} \mathrm{C}$, $[\alpha]_{\mathrm{D}}^{5}-260.44^{\circ}$ (クロロホルム), $n_{\mathrm{D}}^{10} 1.5222, d_{15}^{15} 0.9904$ の油状物 筫を単嶉し，2,4-ジニトロフェニルヒドラゾン, $\mathrm{C}_{27} \mathrm{H}_{30} \mathrm{O}_{8} \mathrm{~N}_{8}$, $\mathrm{mp} 230^{\circ} \mathrm{C}$ を得て, 辛味成分は $\mathrm{C}_{15} \mathrm{H}_{22} \mathrm{O}_{2}$ の分子式をもつジケト ンと推定し，タデオンと命名している。しかしその構造について はその後まったく研究が行なわれていない。

辛味料としてむちいられているいろいろの植物に含まれている 茾味成分として現在までにその㔍造が解明されているすのは,

（1）アミド結合をもつもの（ピペリン，カプサイシン，サンシ ョウオールなど)，(2）イソチオシアネート基定もつもの（シニ グリン, カラシ油など), (3) ジスルフィド結合をるつもの (ジ

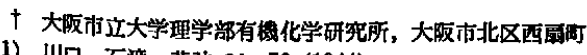

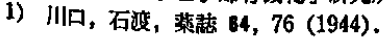

アリルジスルフィドなど）および（4）4-オキシ-3-メトキシフ エニル基をもつもの（ジンゲロン，クルクミンなど）の四つのグ ループに大別される。しかしタデオンは分子式からもあきらかな ようにこのいずれのグループにも属さないまったく別の型の辛 味成分である。そこで著者はこのタデの辛味成分の構造をあきら かにする目的で以下の研究を行なった。

\section{2 実験結果および考察}

開花期直前のヤナギタデを刈り取り，ただちにベンゼンに浸漬 する*1。ベンゼンを減圧下に留去し，得られる黒緑色の粘稠なエ キスから減圧水蒸気蒸留によって精油分をのぞき，残留物を石油 エーテルで抽出して不溶物をのぞく。さらにアルコールにとかし て不溶部をのぞき, 窒素気流中で減圧蒸留すると $\mathrm{bp}_{1} 120^{\circ} \sim 150^{\circ}$ Cの辛味をるつ黄色の油が得られる*2。これを亜硫酸水尧ナトリ

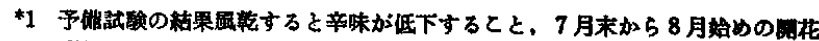

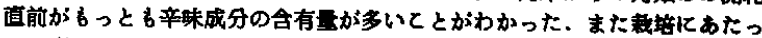
て窒莱盵料を吰すと辛味成分の含有岳がいちじるしく減少する。

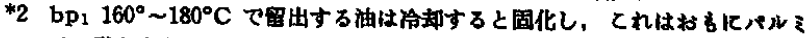

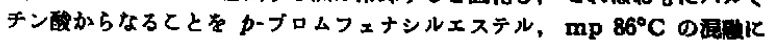
よって確慧した。 
ウムの飽和水溶液と処理し，付加物を水で抽出して放置すると辛 味成分の結晶性付加物が得られ，これを水破化ナトリウムの水溶 液で注意深くアルカリ性にすると， $\mathrm{bp}_{0.8} 138^{\circ} \sim 140^{\circ} \mathrm{C}$ のきわめ て強い辛味をむつ油が得られる。 $n_{\mathrm{D}}^{7} 1.5280,[\alpha]_{\mathrm{D}}-210^{\circ}(95 \%$ エタノール), 冷却すると固化し約 $50^{\circ} \mathrm{C}$ で融解する。2,4-ジ二

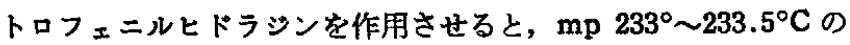
色針状結毘, $\mathrm{C}_{27} \mathrm{H}_{80} \mathrm{O}_{8} \mathrm{~N}_{8}$ 少得られ， タデオンと同一物 と考え 橙られる。しかしあとにのべるようにこのあのはジケトンではな く,ヶトアルデヒドであるのでタデオナールと呼ぶことにする。

タデオナールは塩化鉄反応を示さず，裖硫酸で赤褐色に呈色す る。真索および過マンガン酸カリウムを冷時脱色し，接触還元に より $1 \mathrm{~mol}$ の水素を吸収して辛味をむたないジヒドロタデオナー ルになる。フェーリング溶液を僈元し, ニトロプルシッドナトリ ウムとアルカリで深紅色に旺色する。紫外吸収スペクトルは 229 と $305 \mathrm{~m} \mu$ に極大吸収を示し,赤外吸収スペクトルには $2700 \mathrm{~cm}^{-1}$ (ア゙ルデヒドの C-H), $1715 \mathrm{~cm}^{-1}$ (䬲和カルボニル), $1675 \mathrm{~cm}^{-1}$ $\left(\alpha, \beta\right.$ 不飽和カルボニル), $1640 \mathrm{~cm}^{-1}$ (共役二重結合), $825 \mathrm{~cm}^{-1}$ （三置換二重結合）に吸収がみられる。またタデオールは酸お上 びアルカリに対して不安定であり容易に 辛味を失なってしまう が,とのものは mp $262^{\circ} \mathrm{C}$ の 2,4-ジニトロフェニルヒドラゾン, $\mathrm{C}_{27} \mathrm{H}_{80} \mathrm{O}_{8} \mathrm{~N}_{8}$ をあた光る。このあのはまたタデオナールの 2,4-ジ ニトロフェニルヒドラゾンを 1 滴の濃硫酸と加熱しても得られ, たがいに異性体である*3。

タデオナール(I) を水案化アルミニウムリチウムで還元すると シシオール(I)（p-ニトロ安息香酸エステル, $\mathrm{C}_{29} \mathrm{H}_{32} \mathrm{O}_{8} \mathrm{~N}_{2}, \mathrm{mp} 163^{\circ}$ $\sim 164^{\circ} \mathrm{C}$ )が得られる。更をアルコール中で接触䢬元すると $1 \mathrm{~mol}$ の水素を吸収してモノアルコール(1)（p-ニト口安息香酸エステ u, $\mathrm{C}_{22} \mathrm{H}_{29} \mathrm{O}_{4} \mathrm{~N}, \mathrm{mp} 150.5^{\circ} \sim 151^{\circ} \mathrm{C}$ ) k加水素分解される。I またはI醀酸中で酸化白金をむちいて㣎元するとさらに $1 \mathrm{~mol}$

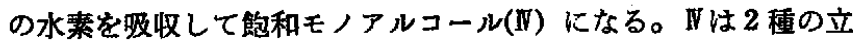
体異性体 $\mathrm{C}_{15} \mathrm{H}_{28} \mathrm{O}, \mathrm{mp} 108.5^{\circ} \sim 109.5^{\circ} \mathrm{C}$ ( $\mathrm{Fa}$ ) $2 \mathrm{mp} 60^{\circ} \mathrm{C}(\mathrm{Fb})$ ( $p$-ニト口安息香酸エステル, $\left.\mathrm{C}_{22} \mathrm{H}_{31} \mathrm{O} 4 \mathrm{~N}, \mathrm{mp} 92^{\circ} \sim 93^{\circ} \mathrm{C}\right)$ との 混合物である。相を酷酸中重クロム酸引ナトリウムで酸化すると

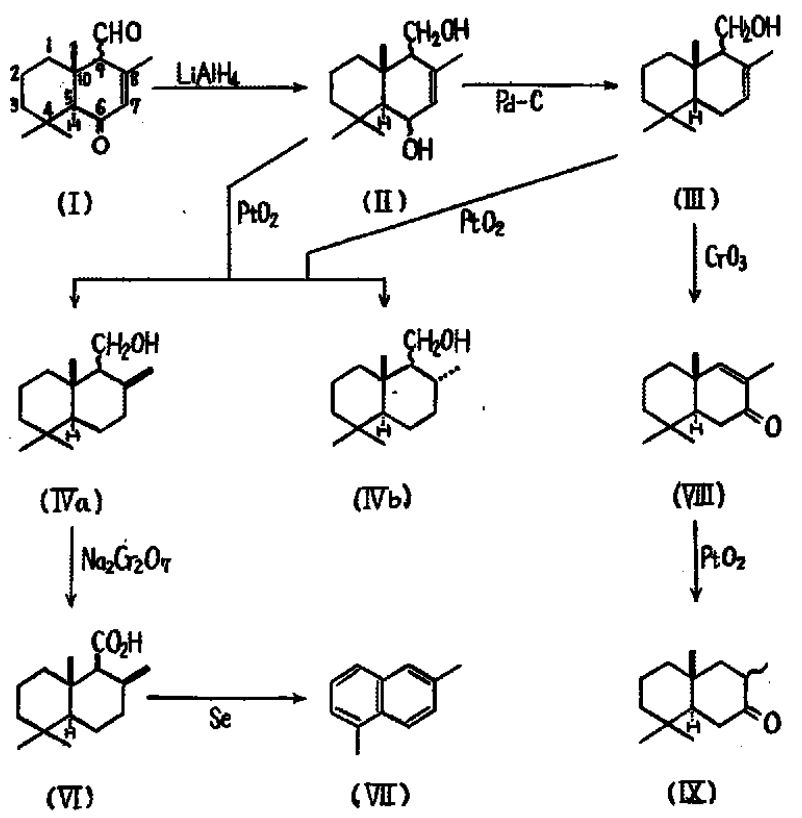

*3 イソタデオナールと呼がてとにする。
$\mathrm{C}_{15} \mathrm{H}_{26} \mathrm{O}_{2}, \mathrm{mp} 132^{\circ} \sim 133^{\circ} \mathrm{C},[\alpha]_{\mathrm{p}}+14^{\circ}$ (クロロホルム)の酸(V) とエステル*4(V) になる。收をセレン脱水素にかける 1,6-シ

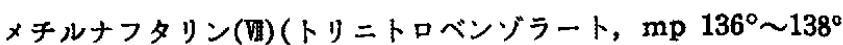
$\mathrm{C}$, ピクラート, $\mathrm{mp} 114^{\circ} \sim 115^{\circ} \mathrm{C}$, スチフナート, $\mathrm{mp} 119^{\circ} \sim$ $120^{\circ} \mathrm{C}$ ) が得られる。一方亚をピリジン中で無水ク口ム酸で酸化 すると炭素数の一つ少ない $\alpha, \beta$ 一不䬲和ヶトン(四) $(2,4$-ジニト ロフェニルヒドラゾン, $\left.\mathrm{C}_{20} \mathrm{H}_{28} \mathrm{O}_{4} \mathrm{~N}_{4}, \mathrm{mp} 178^{\circ} \sim 179^{\circ} \mathrm{C}\right)$ が得ら

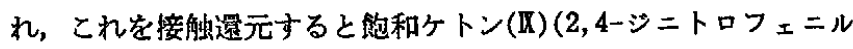
ヒドラゾン, $\mathrm{C}_{20} \mathrm{H}_{28} \mathrm{O}_{4} \mathrm{~N}_{4}, \mathrm{mp} 218^{\circ} \sim 219^{\circ} \mathrm{C}$ ) が得られる。

上に述べた一連の反応は Appel ら² が Drimys wirnteri Forst. から 单離したドリメノール(X) の構造研究において行な っている一連の反応ときわめてょく類似している。すなわちドリ メノール(メ) を䤀酸エステル中で酸化白金を触媒として還元する そ 2 種の立体異性体の飽和アルコール, ドリマノール， $\mathrm{C}_{15} \mathrm{H}_{28} \mathrm{O}$ (IIa), mp $110^{\circ} \sim 111^{\circ} \mathrm{C}$ と $8 \alpha-$ ドリマノール(IIb), mp 60 $62^{\circ} \mathrm{C}$ の混合物になり，さらに 邓a を酶酸中で無水クロム酸で酸

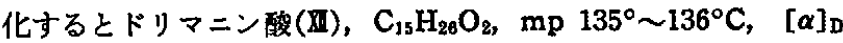

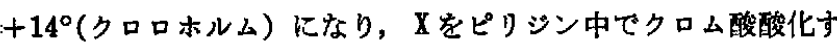

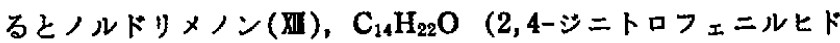
ラゾン, $\left.\mathrm{mp} 175^{\circ} \mathrm{C}\right)$ になると報告されている。

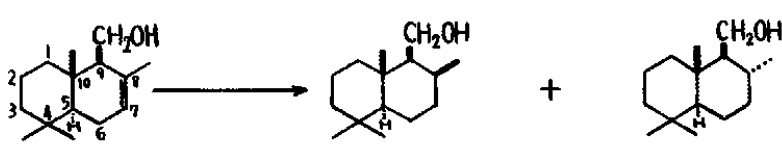

(X)<smiles>CC1=CC2(C)CCCC2(C)CC1=O</smiles>

(XIII)
$\left(\mathrm{XI}_{a}\right)$<smiles>OCC12CCC3CC1CC2C3(O)O</smiles>

(XII)
これらの諸物質と上述のタデオナールからみらびかれるものと

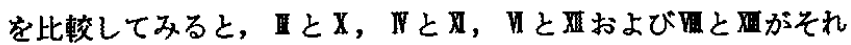
ぞれ同一物ではないかと推定され，脱水装で面の得られるこ ともうなずける。

さいわいにも Appel 教授および Brooks 博士の御厚意によ

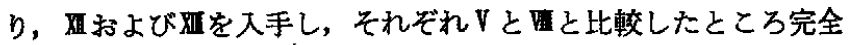
に同一物であることが確定できた。したがってタデオナールの炭 素骨骼と $\mathrm{C}_{(5)}, \mathrm{C}_{(10)}$ の立体構造, さらに II の重結合の位圆が 決定できたととになる。

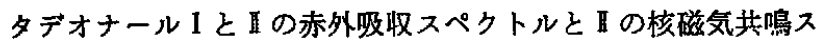
ペクトル $(\tau=4.35)$ はこれらの二重結合が三置換であることを 示しており，Iの二重結合る目と同様に $\mathrm{C}_{(\urcorner)}$にあると推定でき る。この推定が正しいとすると，Iが接触遼元で加水素分解をう けてなるのであるから，二重結合のアリル位すなわち $\mathrm{C}_{(6)}$ にもう一つの第二水酸基が存在しなければならず, したがってタ デオナールには式（I）が与えられる。

タデオナールの $\mathrm{C}_{(\text {g) }}$ の立体構造とその異性体であるイソタデ

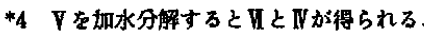

2) H. H. Appel, C. J. W. Brooks, K. H. Overton, J. Chem. Soc. $1959,3322$. 
オナールの榑造については目下研究中である。

\section{3 実 験 の 部*5}

\section{1 タデオナールの単離}

ヤナギタデ(Polygonum Hydropiper var. vulgare L.) の根を 除く全草 $300 \mathrm{~kg}$ を $100 l$ のドラムカン 10 個に入れてベンゼン で2回室淄で潜し，ベンゼンを $100 \mathrm{mmHg} ， 60^{\circ} \mathrm{C}$ 以下で留去 する。黑褐色のエキスを $30 \mathrm{mmHg}$ で水萑気蒸留して精油分を 除く。残留物を茈燥後石油エーテルで抽出し，溶媒を留去したの ち熱エタノールにとかし冷却する。析出するロウ状物質を口別 し, 口液を䟴維し $1 \mathrm{mmHg}$ で蒸留する。

留分 (1) $\mathrm{bp}_{1} 120^{\circ} \mathrm{C}$ 以下, $\quad 113.5 \mathrm{~g}$

留分 (2) $\mathrm{bp}_{1} 120^{\circ} \sim 160^{\circ} \mathrm{C}, 282.0 \mathrm{~g}$

留分 (3) $\mathrm{bp}_{1} 160^{\circ} \sim 180^{\circ} \mathrm{C}, 112.0 \mathrm{~g}$

留分 (2) $282 \mathrm{~g}$ に亜硫酸水素ナトリウム $100 \mathrm{~g}$ の水 $200 \mathrm{cc}$ 溶 液を加え，氷冷下で 24 洔間加きぜる。生じた乳濁液に水 $4 l$ を加え末反応物をエーテル抽出により除く。水溶液を放置すると 結晶性付加物 $11 \mathrm{~g}$ が得られる。水溶液および結晶性付加物を氷 冷下で $6 \mathrm{~N}$ 水酸化ナトリウムで注意深くアルカリ性(フェノール フタレイン）にし，避離する油をエーテル抽出する。水溶液加ら は $32.5 \mathrm{~g}$ ，結晶性付加物からは $6.1 \mathrm{~g}$ の粗タデオナールが得られ た。 bp $0.8138^{\circ} \sim 140^{\circ} \mathrm{C}$, 淡黄色の粘稠な油で冷却すると固化す る。 $\mathrm{mp}$ 約 $52^{\circ} \mathrm{C},[\alpha]_{\mathrm{D}}-211 \pm 6^{\circ}(c=0.017,95 \%$ エタノル), $n_{\mathrm{D}}^{7} 1.5280, \lambda_{\max } 229(\varepsilon=10100), 305(\varepsilon=106) \mathrm{m} \mu, \lambda_{\mathrm{inf}} 270 \mathrm{~m} \mu$, $\nu_{\max } 2700,1715,1675,1640,825 \mathrm{~cm}^{-1}$ (Nujol), 2,4-ジニト ロフェニルヒドラゾン, $\mathrm{mp} 233^{\circ} \sim 233.5^{\circ} \mathrm{C}$, 撜色針状結晶。

分析值 C $54.65 \%, \mathrm{H} 5.23 \%, \mathrm{~N} 18.71 \%$

$\mathrm{C}_{27} \mathrm{H}_{30} \mathrm{O}_{8} \mathrm{~N}_{8}$ としての

計算值 C $54.54 \%, \mathrm{H} 5.08 \%, \mathrm{~N} 18.85 \%$

\section{2 タデオナールの翼性化，イソタデオナール}

タデオナール $1.2 \mathrm{~g}$ を酢酸エステル $50 \mathrm{cc}$ にとかし， 1 滴の濃 硫酸を加えて 30 分間還流すると辛味がまったく失なわれ， $\mathrm{bp}_{3}$ $130^{\circ} \sim 170^{\circ} \mathrm{C}$ (浴温)の粘稠な淡黄色の油 $0.6 \mathrm{~g}$ が得られる。2,4-シ ニトロフェニルヒドラジンを作用させると少量の結晶, $\mathrm{mp} 258^{\circ}$ C(分解) が得られる。これはまたタデオナールの 2,4-ジニトロ フェニルヒドラゾンを酶酸エステル中で 1 滴の濃硫酸を加えて加 熱しても得られる。 $\mathrm{mp} 262^{\circ} \mathrm{C}$ (分解)，橙色針状結晶。

分析值 C $54.65 \% ， \mathrm{H} 5.00 \% ， \mathrm{~N} 18.57 \%$

$\mathrm{C}_{27} \mathrm{H}_{30} \mathrm{O}_{8} \mathrm{~N}_{8}$ としての

計算值 C $54.54 \%, \mathrm{H} 5.08 \%, \mathrm{~N} 18.85 \%$ 3.3 タデオナール(I) の迹元

3.3.1 ジヒドロタデオナール: タデオナール(I) $1.0 \mathrm{~g}$ をエタ

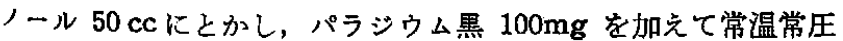
の水素中でふりまぜる。 7 時間で $97 \mathrm{cc}(1.02 \mathrm{~mol})$ の水素を吸収 し, $b p_{0.008} 100^{\circ} \sim 110^{\circ} \mathrm{C}$ (浴温)の浮黄色の油 $1.0 \mathrm{~g}$ が得られる。 $\nu_{\max } 1715 \mathrm{~cm}^{-1}(\mathrm{Nujol}) ， \mathrm{I}$ にみられた $1675 \mathrm{~cm}^{-1}$ の吸収が消失 しており二重結合が還元されたものと考えられる。これはもはや 辛味をるたず，わずかに苦味を感じる。結晶性誘導体は精製でき なかった。

3.3 .2 ジオール(II)：タデオナール(I) $2.0 \mathrm{~g}$ を $70 \mathrm{cc}$ の無 水エーテルにとかし，これを水素化アルミニウムリチウム $2.5 \mathrm{~g}$

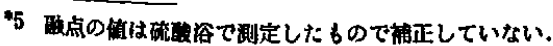

を無水エーテル $125 \mathrm{cc}$ に賏濁した液に $30^{\circ} \mathrm{C}$ 以下にたもちなが ら加える(30分間)。滴加後 7 時間這流して反応を完結させ, 冷却 後酢酸エステル $10 \mathrm{cc}$ 它加えて過剩の摆元绪を分解したのち反応 混合物が完全に透明になるまで $10 \%$ 硫酸 $150 \mathrm{cc}$ を加え, エー テル抽出する。 $\mathrm{bp}_{3} 140^{\circ} \sim 160^{\circ} \mathrm{C}$ (浴温) の無色の油(I) $2.0 \mathrm{~g}$ が得られ冷却すると固化する。 $\nu_{\max } 3300,1662,830 \mathrm{~cm}^{-1}$ (oil)。 $p$-ニトロ安息香酸エステル, $\mathrm{mp} 163^{\circ} \sim 164^{\circ} \mathrm{C}$ 。

分析值 C $64.99 \% ， \mathrm{H} 6.07 \% ， \mathrm{~N} 5.28 \%$

$\mathrm{C}_{29} \mathrm{H}_{32} \mathrm{O}_{8} \mathrm{~N}_{2}$ としての

計算值 C $64.91 \% ，$ H $6.01 \% ， N 5.22 \%$

3.4 モノアルコール(III)

シオール(I) $1.2 \mathrm{~g}$ を $n$-ヘキサン $30 \mathrm{cc}$ とエタノール $20 \mathrm{cc}$ の混合溶媒にとかし，5\% パラジウム炭索 $1.0 \mathrm{~g}$ を加えて㯰元す る。最初の $1 \mathrm{~mol}$ の水素を約 1 時間で吸収し，そののちきわめ てゆるやかに吸収をつうける。12 時間で約 $1.2 \mathrm{~mol}$ 吸取したと ころで還元をやめる。溶媒を留去すると粘稠な油(IV) $1.2 \mathrm{~g}$ が得 られる。 $p$-ニト口安息香酸エステル*6, mp $150.5^{\circ} \sim 151^{\circ} \mathrm{C}$ 。

分析值 C $71.08 \%, \mathrm{H} 7.83 \%, \mathrm{~N} 3.83 \%$

$\mathrm{C}_{22} \mathrm{H}_{29} \mathrm{O}_{4} \mathrm{~N}$ としての

計算值 C $71.13 \% ， \mathrm{H} 7.87 \% ， \mathrm{~N} 3.77 \%$

3.5 的和モノアルコール(IV)

3.5.1 ジオール(II) の远：ジオール(I) $0.54 \mathrm{~g}$ を酢酸 45 cc にとかし，酸化白金 $0.05 \mathrm{~g}$ を加えて 還元すると約 3 時間て $2 \mathrm{~mol}$ の水索を吸叹し, $\mathrm{bp}_{1} 120^{\circ} \sim 140^{\circ} \mathrm{C}$ (浴温) の油(IV) 0.49 g が得られる。 N 0.48 をと゚りジン $5 \mathrm{cc}$ にとかし p-ニトロ 安息香酸クロリド $0.8 \mathrm{~g}$ を加えて 2 分間加熱溶解し 1 夜放置す る。水を加えて生ずる沈殿をベンゼン抽出する。種々の溶媒から 再結晶を試みたが結晶化しないので，アルミナをるちいてクロマ トグラフにかけベンゼンで溶出した。第 1 区分から mp 930 940 Cの結晶*7が得られた。

分析值 C $70.85 \%$, H $8.35 \%, N 3.61 \%$

$\mathrm{C}_{22} \mathrm{H}_{31} \mathrm{O}_{4} \mathrm{~N}$ としての

計算値 C 70.75\%， H 8.37\%，N $3.75 \%$ 第3 区分も結晶化するが完全には精製できなかった。

3.5.2 モノアルコール(III) の還元：モノアルコール(I) 1.0 g を酢酸 $50 \mathrm{cc}$ にとかし酸化白金 $0.1 \mathrm{~g}$ を加えて遗元する。 1.5 時間で $1 \mathrm{~mol}$ の水素を吸取し $\mathbb{1} 0.9 \mathrm{~g}$ が得られる。

\section{6 飽和モノアルコール(IV) の酸化}

飽和モノアルコール(V) $10 \mathrm{~g}$ を酢酸 $70 \mathrm{cc}$ にとかし, 氷命下 に重クロム酸ナトリウム $6 \mathrm{~g}$ の酢酸 $60 \mathrm{cc}$ 溶液を加える。室温 に 1 夜放置したのち，過剩の酸化埥をメタノール $10 \mathrm{cc}$ で分解 し, 水でうすめてエーテル抽出する。水洗後 $1 N$ 水酸化ナトりウ ムで抽出して酸性部と中性部にわける。

酸性部をジアゾメタンでメチル化し 蒸留すると $\mathrm{bp}_{1.5} 100^{\circ}$ $107^{\circ} \mathrm{C}$ のメチルエステル $5.0 \mathrm{~g}$ が得られる。このエステルをト リエチレングリコール中で加水分解すると $b_{1.5} 120^{\circ} \sim 160^{\circ} \mathrm{C}$ (浴温) の酸(U) が得られる。椧却すると固化し，60\% 含水メ タノールから再結晶する。 $\mathrm{mp} 132^{\circ} \sim 133^{\circ} \mathrm{C},[\alpha]_{\mathrm{D}}+13.8^{\circ}(c=$ 1.085 , クロロホルム)。

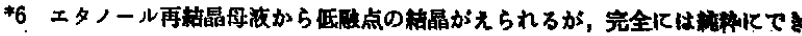
なかった。

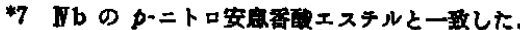


分析值 C $75.59 \%$, H $10.94 \%$

$\mathrm{C}_{13} \mathrm{H}_{26} \mathrm{O}_{2}$ としての計算值 C $75.58 \%$, H $11.00 \%$

ドリマニン酸と旋光度, 混融および赤外吸収スペクトルで完全 に一坟した。

中性部からは, $\mathrm{bp}_{1.5} 107^{\circ} \sim 117^{\circ} \mathrm{C}$ の油(V) $3.9 \mathrm{~g}$ が得られ, $\nu_{\max } 1730,1230 \mathrm{~cm}^{-1}$ (oil) よりエステルと考えられる。エタノ 一ル中で $2 \mathrm{~N}$ 水酸化カリウムを加兄て加水分解すると，酸性部か らは】が得られ，中性部からはアルミナをむちいたクロマトグラ フにより $\mathrm{mp} 108^{\circ} \sim 109^{\circ} \mathrm{C}$ の無色針状結晶*8(Na) と $\mathrm{mp} 60^{\circ} \mathrm{C}$ のロウ状物質(IV) が得られる。

Va の分析値 C $80.32 \%$, H $12.43 \%$

$\mathrm{C}_{15} \mathrm{H}_{28} \mathrm{O}$ としての計算值 C $80.29 \%$, H $12.58 \%$

Irb の p-ニトロ安息香酸エステル, $\operatorname{mp~} 93^{\circ} \sim 94^{\circ} \mathrm{C}$ 洋前述の Nから得られたものと一致した。

3.7 鞿(VI) の脱水素，1,6-ジメチルナフタリン

酸(V) $1.37 \mathrm{~g}$ にレン末 $5 \mathrm{~g}$ を加えて窒素気流中で $330^{\circ} \sim$ $340^{\circ} \mathrm{C}$ K 11 時間, $340^{\circ} \sim 350^{\circ} \mathrm{C}$ に 11 時間加熱した。 $b_{3} 60^{\circ}$ $\sim 110^{\circ} \mathrm{C}$ (浴温) の油 $0.45 \mathrm{~g}$ が得られる。

トリニトロベンゾラート mp $137^{\circ} \sim 139^{\circ} \mathrm{C}$, 黄色針状結晶。

分析值 C $58.92 \%, \mathrm{H} 4.15 \%, \mathrm{~N} 11.13 \%$

$\mathrm{C}_{18} \mathrm{H}_{15} \mathrm{O}_{6} \mathrm{~N}_{3}$ としての

計算值 C $58.53 \%$ ， H $4.09 \% ， \mathrm{~N} 11.38 \%$

トリニトロベンゾラートをアルラナの層を通して炭化水素を再 生した。ピクラート, $\mathrm{mp} 114.5^{\circ} \sim 115.5^{\circ} \mathrm{C}$, 橙色針状結晶。

分析犆 C $56.20 \%, \mathrm{H} 4.09 \%$

$\mathrm{C}_{18} \mathrm{H}_{15} \mathrm{O}_{7} \mathrm{~N}_{3}$ としての計算俌 C $56.10 \% ， \mathrm{H} 3.92 \%$ スチフナート, $\mathrm{mp} 119^{\circ} \sim 120^{\circ} \mathrm{C}$, 橙色針状結晶。

3.8 不能和モノアルコール(III) の陵化, ノルドリメノン 不䬲和モノアルコール(I) $0.5 \mathrm{~g}$ をピリジン $10 \mathrm{cc}$ にとかし，

*8 $p$-ニトロ安息香酸エステルは赫粦て得られなかった。
これを無水クロム酸 $0.6 \mathrm{~g}$ をピリシン $20 \mathrm{cc}$ に加えた液に $0^{\circ} \mathrm{C}$ で加える。室温で 1 夜放䈯後水を加えてェーテル抽壮すると， $0.45 \mathrm{~g}$ の油(图) が得られる。 $\nu_{\max } 1670 \mathrm{~cm}^{-1}$ (oil) で $\alpha, \beta-$ 不飽和ケトンと考光られる。2,4-ジニトロフェニルヒドラゾン， $\operatorname{mp} 178^{\circ} \sim 179^{\circ} \mathrm{C}$, 赤撜色針状結晶。

分析值 C $61.88 \%, \mathrm{H} 6.79 \%, \mathrm{~N} 14.43 \%$

$\mathrm{C}_{20} \mathrm{H}_{20} \mathrm{O}_{4} \mathrm{~N}_{4}$ としての

計算値 C $62.16 \%, \mathrm{H} 6.78 \%, \mathrm{~N} 14.50 \%$

ノルドリメノン, 2,4-ジニトロフェニルヒドラゾン, $\operatorname{mp} 178^{\circ}$ $\sim 179^{\circ} \mathrm{C}$ と混融により一致した。

3.9 ジヒドロノルドリメノン

$\alpha ， \beta$-不飽和ヶトン(晒) $0.5 \mathrm{~g}$ 它酢酸中で酸化白金をもちいて 這元すると， 1.5 時間で約 $1 \mathrm{~mol}$ の水素を吸取する。少量のアル コールが副生しているため酢酸中で重クロム酸ナトリウムで酸化 すると飽和ヶトン(IX) $0.35 \mathrm{~g}$ が得られる。 $\nu_{\max } 1700 \mathrm{~cm}^{-1}$ (oil), 2,4-ジニトロフェニルヒドラゾン, $\operatorname{mp} 218^{\circ} \sim 219^{\circ} \mathrm{C}$, 责色針状 結鼠。

\author{
分析値 C $61.88 \%, \mathrm{H} 7.29 \%$ N $14.33 \%$ \\ $\mathrm{C}_{20} \mathrm{H}_{28} \mathrm{O}_{4} \mathrm{~N}_{4}$ としての \\ 計算值 C $61.84 \%, \mathrm{H} 7.27 \%, \mathrm{~N} 14.42 \%$
}

本研究にあたり終始御䈍第な御指導な賜わった恩師小竹繁二雄 先生に心から御礼申し上げる。また原料のナナギタデの栽培に御 尽力下さった玉利幸次郎助教授，庵原抙助教授はか大阪市立大 学理学部付属植物園の皆様, 試料ないただいたチりーサンタマリ ア大学の Appel 教授, 英国グラスゴウの Brooks 博士, 元素分 析，赤外䏜収スペクトルを和碩いした大阪大学理学部，大阪市立

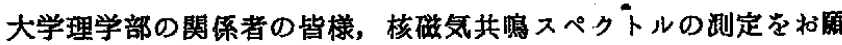
いした東京教育大学中西香爾教授に厚く辱謝する。

\title{
プロムマロン酸誘䒺体とアセトアミド金属㙁との反応
}

\author{
（昭 和 37 年 2 月 5 日受理）
}

小田大平.下光太郎

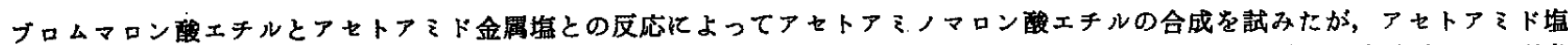
は単飞嫶基として作用するにすぎず，主生成物としてはエチレンテトラカルボン酸エチルが得られた。本反応が分子間からの瞣臭 化水素によって生ずるブロムエタン化合物を経由するものが，あるいは分子内で脱臭化水素したカルベンを経由するかてついて考 察觉加光た。

フタルイミノマロン酸エステルはフタルイミドカリウムとブロ ムマロン酸エステルとの反応で容易につくられるほ。著者らはア セトアミドが液体アンモニア（以下液安と略称）中金属アルカリ によって簡単にアルカリ塩となる点に着目し，これをブロムマロ ン酸エチル（以下EBMと略称）と反応させてアセトアミノマロ ン酸エチルを合成しようとした。

まず，液安中での反応は E BMと液安との反応性を考虑して $-40^{\circ} \mathrm{C}$ 以下の低温で行なうこととし，反応モル比や金属塩の種 類を変えていろいろの条件で行なったが，結果は表 1 に示される とおりいずれの場合む主生成物としてエチレンテトラカルボン酸 エチル (以下E T C と略称)，1-アミノエタン-1,1,2,2-テトラカ ルボン酸エチル(以下AETCと略称)*1ならびにアセトアミドが 得られた以外に予期したるのは認められなかった。液安を除いて

*1 AETC はいったん生した ETCにアンモニアが付加して生したるのと考れ。 られ，事実ETCは洨安または源アンモニア水との接脑により容易にAETC そ変わる。 